University of New Mexico

UNM Digital Repository

$12-1-2010$

\title{
Twenty-eight years of the US-LTER Program: Experience, results, and research questions
}

James R. Gosz

University of Idaho

Robert B. Waide

University of New Mexico

John J. Magnuson

University of Wisconsin-Madison

Follow this and additional works at: https://digitalrepository.unm.edu/Iter_reports

Part of the Ecology and Evolutionary Biology Commons, and the Environmental Studies Commons

\section{Recommended Citation}

Gosz, James R.; Robert B. Waide; and John J. Magnuson. "Twenty-eight years of the US-LTER Program: Experience, results, and research questions." (2010). https://digitalrepository.unm.edu/lter_reports/160

This Article is brought to you for free and open access by the Museums and Research Centers at UNM Digital Repository. It has been accepted for inclusion in Long Term Ecological Research Network by an authorized administrator of UNM Digital Repository. For more information, please contact disc@unm.edu. 
Twenty-eight years of the US-LTER Program: Experience, results, and research questions

James R, Gosz, University of Idaho

Robert B. Waide, University of New Mexico and the US LTER Network Office ${ }^{1}$

John J. Magnuson, University of Wisconsin - Madison

Introduction

The U.S. Long Term Ecological Research program (hereafter US-LTER) concentrates on ecological processes that play out at time scales spanning decades to centuries. This focuses US-LTER research between the most common time scales for ecological studies (1-3 years; Tilman 1989; Figure 1) and the much longer temporal foci of disciplines such as paleoecology. The importance of the decade-to-century time scale is particularly evident in light of the rapid changes in ecological forcing functions that are occurring at a broad range of spatial scales (Millennium Ecosystem Assessment 2005, Intergovernmental Panel on Climate Change 2007). Long-term data sets from programs such as US-LTER provide a context to evaluate the pace of ecological change, to interpret its effects, and to forecast the range of future biological responses to change.

Although many US research sites and programs collect data over long time spans, the US-LTER is the only one that intensively addresses the interactions of multiple ecosystem processes acting over long time scales. Moreover, the 26 sites constituting the US-LTER function as a network to compare long-term trends and synthesize the results of those comparisons into general principles that underlie the behavior of ecosystems (LTER 2007). Long-term data sets in the US arise from many sources, including research programs sponsored by federal and state agencies (e.g., the Department of Energy's National Laboratories), monitoring programs instituted to support resource management and conservation (e.g., the Bird Breeding Survey), monitoring networks focused on environmentally significant factors (e.g., the National Atmospheric Deposition Program), and efforts to document trends in specific parameters undertaken by agriculturalists, academicians, conservation organizations, and private citizens. The existence of these other long-term data provides a wealth of information that complements results from the US-LTER and extends understanding beyond individual research sites.

\section{Description of the US-LTER Program}

Twenty-six research sites constitute the US-LTER at present (Figure 2). These 26 sites include a wide range of ecosystem types spanning similarly broad ranges of environmental conditions and degrees of human domination of the

\footnotetext{
${ }^{\prime}$ Corresponding author: Robert B. Waide, Department of Biology, MSC03 2020, 1 University of New Mexico, Albuquerque, NM USA 87131; phone: 505/277-2649; fax: 505/277-2541; rwaide@Iternet.edu
} 
landscape. The geographic distribution of sites ranges from Alaska to Antarctica and from the Caribbean to French Polynesia. The US-LTER Network includes agricultural lands, alpine tundra, barrier islands, coastal lagoons, cold and hot deserts, coral reefs, estuaries, forests, freshwater wetlands, grasslands, kelp forests, lakes, open ocean, savannas, streams, and urban landscapes. In addition to this wide range of ecosystem types, many sites encompass significant heterogeneity within their particular ecosystems. Each site develops individual research programs in five core areas: pattern and control of primary production; spatial and temporal distribution of populations selected to represent trophic structure; pattern and control of organic matter accumulation in surface layers and sediments; patterns of inorganic inputs and movements of nutrients through soils, groundwater and surface waters; and patterns and frequency of site disturbances. The National Science Foundation (NSF) initially funded sites att $\$ 250,000$ yr staring in 1980. Perlodic horeases haveresultedin current füling levels of $\$ 820,000$ per year through renewable, six-year grants for base funding

Sites in the US-LTER Network average 18 cooperating investigators and 20 graduate students per site (US-LTER Network Office, unpublished data). In addition, between 10 and 150 additional investigators make use of the research infrastructure provided at sites. Support for these additional researchers comes from many sources and augments the base funding available for research at sites by a factor of 2.9. Each of the 26US-LTER sites integrates an education program with its research agenda. All sites incorporate graduate and undergraduate education in their programs, and most sites have kindergarten through $12^{\text {th }}$ grade programs as well.

Network-scale research initiatives are developed through intensive planning activities (LTER 2007) and fostered by annual meetings of a Science Council with representatives from each site and triennial meetings that involve most USLTER investigators. The Network research agenda is supported by a coordinated program of information management that involves data managers from each site, common metadata standards, and a centralized information architecture that provides access to site data. The integration of data collection and data management activities provides a strong basis for cross-site and network synthesis.

The US-LTER is governed by an elected Chair and an Executive Board comprised of nine rotating site representatives and one member selected to provide expertise on information management. Eight standing committees (Climate, Education, Graduate Students, Information Management, International, Network Information System, Publications, and Social Science) support and inform the governance process. A Network Office, funded separately by the National Science Foundation, facilitates research, education, information management, and governance activities. 
Goals - The mission of the US-LTER Network at this writing encompasses six goals:

Understanding: To understand a diverse array of ecosystems at multiple spatial and temporal scales.

Synthesis: To create general knowledge through long-term, interdisciplinary research, synthesis of information, and development of theory.

Information: To inform the US-LTER and broader sclentific community by creating well designed and well documented databases.

Legacies: To create a legacy of well-designed and documented long-term observations, experiments, and archlves of samples and specimens for future generations.

Education: To promote training, teaching, and learning about long-term ecological research and the Earth's ecosystems, and to educate a new generation of scientists.

Outreach: To reach out to the broader scientific community, natural resource managers, policymakers, and the general public by providing decision support, information, recommendations and the knowledge and capability to address complex environmental challenges.

Three examples of the kinds of results that come from US-LTER research are provided in the following boxes. These examples demonstrate how LTER research can help uncover the causes of an outbreak of human disease, how LTER science can generate new concepts that involve both space and time, and how an LTER site can contribute to evaluating competing needs for water.

\section{Ecological Correlates to the Spread of Hantavirus}

Unexpected events (i.e., ecological surprises) driven by new phenomena or different combinations of variables that occur on an infrequent basis generate new questions and new discoveries. An example occurred in the North American Southwest in 1993 when a serious outbreak of a disease, subsequently identified as hantavirus (Nichol et al., 1993), caused the deaths of nearly half of the people that contracted it. Research from the Sevilleta LTER project (Figure 3) helped make possible the rapid discovery of the cause of the outbreak of the virus because the project was unique in the Southwest in having the necessary historical data and museum specimen collections to provide the critical information. Virus identification led to vector identiflcation, the deer mouse (Parmenter et al. 1993, Childs et al. 1994). Yates et al. (2002) showed that the outbreaks of hantavirus in 1993 and in 1998-2000 were associated with the 
warm-phase of the (ENSO) phenomenon that produced increased amounts of fall-spring precipitation in the arid and semi-arid regions of New Mexico and Arizona, and greater production of rodent food resources. These abundant food resources allowed greater reproduction in rodents that dispersed across the landscape and came into contact with humans in homes and businesses. The scientists also were able to confirm the existence of the deadly virus in tissues archived in the museum's collections prior to the original outbreak in 1993, proving the "new" virus had been present in New Mexico probably for millions of years and was just now being discovered.

The value of the contribution has been identified by NSF as one of the 50 discoveries made with NSF funding that have had the most influence or biggest impact on the lives of Americans. Highlighted in an NSF publication titled, "Nifty 50 ", the discoveries were chosen from 10's of thousands of NSF-funded projects since its inception in 1950. This represents a classic case for the importance of long-term, basic research in helping to solve real societal problems.

\section{The Importance of Landscape Position}

The concept the landscape position of lakes in the hydrologic flow system provides an important context for the factors that determine the status and dynamics of lakes (Kratz et al. 1991, Webster et al. 1996, Kratz et al. 1997, Magnuson and Kratz 2000, Riera et al. 2000, Webster et al. 2000, Kratz et al. 2006). It parallels, in some ways, stream continuum concept (Vannote et al. 1980, Thorp and Delong 1994).

In respect to status or condition, the position of lakes from high to low in the hydrologic flow paths at the North Temperate Lakes LTER determines, in part, the concentrations of phytoplankton and dissolved solids, and fish species richness (Figure 4 from Kratz et al. 2006). A diverse set of other features, i.e., lake morphometry, optical properties, lon and nutrient concentrations, biology, and even human variables, are related to landscape position.

Landscape position is not a direct cause of these differences but a context related to more proximate factors that differ with landscape position.

Concentrations of nutrients and other dissolved ions depend very much on the water source with precipitation (lower concentrations) dominating high in the landscape and surface and groundwater (higher concentrations) dominating low in the landscape. Lakes high in the landscape are more isolated from fish immigration because these higher lakes do not have surface streams. Lakes high in the landscape are less productive because they receive fewer nutrients in their water sources than do lakes lower in the landscape.

Landscape position also influences dynamics. During a drought over several years, lakes higher in the landscape (seepage lakes) had greater declines in water level than lakes low in the landscape, i.e., not only was precipitation lower, 
but seepage lakes received almost no groundwater during the drought (Webster et al. 1996). Lakes high in the landscape also had greater interannual variation in chemical concentrations (Kratz et al. 1991) owing to their greater responsiveness to drought.

The geomorphic template for landscape position of lakes is a legacy from geological events that patterned the landscape, in northern Wisconsin the retreat of the continental glaclers some 12,000 years ago. Thus, the influence of landscape position on lake status and dynamics is remarkably stable in ecological time, much more stable than the decade and century dynamics in ecological time.

Managing Water in Tropical Catchments

Increasing population, growth in tourism and industry, and agricultural needs combine in many parts of the tropics to create significant pressure on regional water supplies. This global issue has been addressed by the development of integrated water resources management initiatives, which are promoted by programs such as Hydrology for the Environment, Life and Policy (HELP), a joint effort of the United Nations Educational Science Organization (UNESCO) and the World Meteorological Organization (Ortiz-Zayas and Scatena 2004). The problem is particularly acute on tropical islands, where groundwater resources are too limited to meet the demands of rapidly increasing populations (March et al. 2003). On these islands, dependence on surface water has led to a proliferation of small dams, the effects of which are poorly known. Because the majority of native macrofaunas in these islands migrate between rivers and coastal zones as part of their life cycle, the impact of dams is potentially great (March et al. 2003).

In Puerto Rico, long-term monitoring data and intensive studies of the biology of stream organisms conducted at the Luquillo LTER site provided the information necessary to evaluate the effects of dams and suggest alternative approaches. The effects of small dams on stream organisms are variable in the Luquillo Mountains depending on the structure of the dam, but in most cases dams serve as bottlenecks to migrating organisms (Benstead et al. 1999, Fievet et al. 2001). For example, densities of juvenile fishes and shrimp migrating upstream increased below the dam, where the concentration of migrating organisms attracted a variety of predators (Benstead et al. 1999). Water withdrawal at the same dam led to high levels of mortality in shrimp larvae migrating downstream. In addition, the existence of dams alters physical habitat and the flow regime both upstream and downstream from the dam. The combined result of these effects can lead to changes in benthic community composition, increases in organic matter and sediment, and decreased rates of in-stream litter decay (Pringle et al. 1999, March et al. 2001, March et al. 2002). 
The effects of dams can be mitigated by maintaining existing fish and shrimp ladders and retrofitting dams without ladders (March et al. 2003). Knowledge of the biology and behavior of stream fauna can further mitigate the effects of water intakes through alterations in operating schedules. For example, Benstead et al. (1999) showed that larval shrimp mortality could be greatly reduced by limiting water extraction during the peak hours of downstream migration. A viable alternative to low-head dams is an in-channel withdrawal system combined with water storage outside of the stream channel. This type of system in the Rio Mameyes in the Luquillo Mountains minimized the mortality of migrating organisms as well as the physical effects on the stream channel when compared to streams with low-head dams (March et al. 2003).

The importance of these measures is significant in Puerto Rico, where migrating stream organisms comprise a substantial portion of the diet of commercially important coastal fishes (Corujo 1980, Pringle 1997, March et al. 2001) as well as food and recreation for local human populations. The global impact may also be significant, since approximately 800,000 small dams exist worldwide (Rosenberg et al. 2000). The capacity to design low-impact water extraction systems depends on the avallability of long-term records of flow rates and population fluctuations, such as those that exist in the Luquillo LTER program.

Two network science studies serve as examples of findings that could not be reached with site-level science: (1) a fleld experiment of forest litter decomposition and (2) variability in North American ecosystems.

(1) In the cross-site experiment of litter decomposition, standard sets of tree leaves were placed in bags at 21 terrestrial ecosystems (17US-LTER sites) for 10 years. Even with the diversity among ecosystems types, differences in nitrogen release into the soil from litter bags were explained by the same two factors - the beginning concentrations of nitrogen in the litter and the amount of organic matter remaining. Such a robust result simplifies modeling of nitrogen release from litter decomposition as a nonecosystem unique process. (http://www.fsl.orst.edu/lter/research/intersite/lidet.htm)

(2) The analysis of variability in North American ecosystems used US-LTER site data to make, general conclusions about spatial (position in the landscape) and temporal (inter-annual) variability within lake, stream, forest, grassland, alpine tundra, and deserts ecosystems. The study used climatic chemical, plant, and animal measures from each of 12 LTER sites. General and simple principles evolved from the analyses (Magnuson et al. 1991, Kratz et al. 1995). Relative variance increased from climatic, to edaphic, to plant, to animal variables. Additionally the proportion of variance explained by location in a landscape was greater than that explained by year for edaphic, plant, and animal measures. That such general emerging properties were robust across ecosystem types was 
initially surprising and demanded consideration of the causal basis of these general features of variability in North American ecosystems.

\section{Origin and history of the US-LTER Program}

Precursors - Long-term ecological or sustained ecological research became formalized in the United States as a National Science Foundation program originating from a natural evolution in the ecological sciences. Ecologists were well aware of the benefits of long-term observation and analyses from pioneering studies by Likens and Borman (1977) on Hubbard Brook, Edmondson (1991) on Lake Washington, and others at Windermere and elsewhere in Europe. They knew that extended time scales revealed new information, new phenomena, and new processes not apparent in short-term study. Ecologists were frustrated because funding sources were not available to more generally examine these important time scales except by piecing together a sequence of short-term projects or from monitoring by applied agencies or a diversity of groups that usually considered a limited number of parameters.

Long-term ecological research also grew out of a history of ecosystem studies from Forbes (1887), Tansley (1935), and Lindeman (1942) and from growing experience with large-scale interdisciplinary programs, especially the International Biological Program (Golley 1993). Despite the advances made by these programs, ecologists were not able to routinely address the important ecological questions and ideas that played out over decades to centuries or that required comparisons among ecosystems and ecosystem types.

The focused development of ideas and possibilities for long-term research were stimulated in 1977 by a report by The Institute for Ecology (1977) called Experimental Ecological Reserves; a Proposed National Network (TIE 1977). The rationales for setting up such a network were to provide sites for suitable ecological experiments in representative ecosystems, to support facilities for field sites, to ensure suitable baselines for responses of ecosystems, to encourage coordination so that researchers can complement each other in the study of complex ecosystem patterns, and to improve communication and cooperation between researchers and users of ecological knowledge. Subsequently, NSF sponsored three workshops from 1977 through 1979 to explore and provide the basis for long-term sustained, ecological research in the United States (Callahan 1984, Franklin et al.1990). The leadership and the interaction of a number of NSF staff, especially John Langdon Brooks and James Thomas Callahan (Magnuson et al. 2006), were apparent.

Participants in these NSF workshops believed that the approach being proposed was of great value to advances in ecological sciences. They also knew that even though many came from programs that might compete for the new resources, not all worthwhile sites could be supported. Rather than select sites directly, they 
provided criteria for sites that could be used in the later selection process. Practical elements were dealt with such as guidelines for establishing long-term ecological measurements, the next steps toward implementation, enumeration of desirable long-term measurements, initial conditions, site characteristics, and intra-and inter-site coordination. The ideas were broadened to ensure a diverse suite of ecological sub-disciplines, i. e., not just ecosystem ecology, and provide opportunities for individual investigators in early efforts to reduce sub-disciplinary barriers among ecologists.

The reasons to initiate a Long-Term Ecological Research Program were enunciated by Marzolf (1982) at the beginning of the US-LTER program.

1. Investigations of ecological phenomena occurring at the time scales of decades and centuries were not normally supported by NSF funding in ecology.

2. Ecological experiments were conducted with little recognition of the high inter-annual variability in studied ecosystems.

3. Long-term trends were not being systematically monitored in ecological systems with the consequence that unidirectional changes could not be distinguished from more cyclic variation.

4. The absence of a coordinated network of ecological research sites inhibited comparative research and its benefits.

5. Natural ecosystems where research was being conducted were being lost to other uses.

6. Ecological research was often done on only a selected component of the system, and multilevel, integrated data were not available at intensive research sites.

Initiation - The call for proposals was made by NSF in 1979 for funding in October 1980. Of the many proposals received, six sites were funded for an initial 6 years at $\$ 250,000$ per year per site. NSF based funding choices among proposals on independent peer review by the ecological community. Choices were made on the basis of the individual proposals rather than an overarching plan designating the array of ecosystems needed in a national program. Funded sites in the first competition were Andrews Experimental Forest, Jornada Basin, Konza Prairie, Niwot Ridge, North Inlet Estuary, and North Temperate Lakes.

Leaders at these six sites were called to NSF's Washington DC office in October 1980 to discuss the program and establish a network for the inter-site aspects of the program. The NSF Program Officer for US-LTER convened the meeting. All the research that had been proposed in the original proposals was rather site specific with little thought being given to the network and inter-site research. This meeting reminded the participants of the network side of the equation and, with NSF's not so gentle urging, the lead principal investigators took the first steps in developing a network among the six sites and presumably any subsequent sites. A Principal Investigator from an LTER site was selected as chair, followed by the 
establishment of several inter-site committees including data management and several of the core areas specified in the call for proposals. Later chairs for the network continued the support and establishment of LTER committees to address specific needs and opportunities.

Site leaders began to meet as a network with support from network-level proposals funded by NSF. Attempts to conduct inter-site research and synthesis developed falteringly, but were stimulated by supplemental funding opportunities that were provided by NSF from the late 1980s until the mid-1990s. In 2006, the US-LTER established a Science Council, which has the role of planning and developing network level science. The establishment of this body was provoked by several key considerations and changes in network governance including the continuing emphasis by NSF and decadal reviews of the US-LTER program on advancing network science, the re-location of the LTER Network Office to the University of New Mexico in 1997 with Robert B. Waide as Executive Director, and the formation of an Executive Board in 2006 to deal with the management issues of the network allowing the Science Council to focus on network science.

The developing science of the US-LTER is reviewed and synthesized in key papers by Tom Callahan (1984), in preparation for the 10-year review of the program (Magnuson 1990, Swanson and Sparks 1990, Franklin et al. 1990), in response to the 20-year review (Hobbie et al. 2003), and in a growing number of site synthesis books (http://intranet.Iternet.edu/commiltees/publications/oxford/).

Data management has been a key investment for the sites, Network Office and entire US-LTER Network. The US-LTER program has been recognized as leading many aspects of information management because of its key role in collaboration among investigators and synthesis of results both within and across the Network of sites (Michener and Brunt 2000, Hobbie et al. 2003). The history of developing this leadership started from the need to archive important longterm data sets, finding comparable archiving methods, facing the challenges of changing technologies for making data available, changing the culture among scientists to allow and promote data sharing, developing capabilities for tremendous increases in the volumes of data from new technologies, training new generations of data managers, and finally, providing the services needed for the entire Network through appropriate staffing and capabilities developed at the US-LTER Network Office (http://lno.Iternet.edu/services/). These services are based on the needs in Core Services, Cyberinfrastructure Support, Development and Outreach, and Synthesis Support. The types of services for these needs are collaboration support, consulting services, database support, data center services, email support, event support, outreach, training and supporting various working groups for the Network.

Increases in sites and funding - The network of sites dedicated to long-term ecological research in the United States has grown steadily since it was formed in 1980 (Figure 5). In addition to adding individual sites, the focus of the network 
has shifted from a concentration on individual site research to a broader synthetic view. As funding increased (Figure 6), expectations of results have shifted to include not only individual researcher, single-site products but also cross-site, network-wide, and international collaborative studies. The goal of these latter studies is to search out general ecological principles that apply to many ecosystems at many different scales. Comparative and synthetic approaches have become the norm in the US-LTER Network.

At the same time that the Network was expanding its scope, the National Science Foundation initiated efforts to broaden participation in LTER research. The purpose of these efforts included a desire to involve additional investigators at satellite research sites, an interest in attracting scientists from different disciplines, and a need to apply results from US-LTER research to the solution of societal problems. Trial efforts to expand the studies conducted at individual sites were implemented at the Coweeta and North Temperate Lake sites by inviting the participation of social scientists and by expanding the geographical scale of the research. More recently, this trend has been carried further through an intensive planning effort (see below).

Governing an expanding network - The planning for an expanded research and education effort resulted in a new governance structure better suited to the coordination and management of the complexity inherent in network-level science (Figure 7). The lead Principal Investigator (PI) of each site plus a rotating representative from that site and eight chairs of standing network committees make up a 60 member Science Council led by a chairperson elected for a 2-year term. The Science Council includes site scientists chosen to represent a diversity of research interests and sites. Science Council business is mostly limited to science-related reports and bylaw revisions, leaving operational decisions to a 12-member Executive Board, which is authorized to act on the Council's behalf. The Executive Board, acting on behalf of the Science Council, is responsible for implementing the Network research plan. The Executive Director of the LTER Network Office is an ex officio member of the Science Council and Executive Board.

The global LTER network - Incorporating international awareness and participation is a critical aspect of the LTER Network initiative-from research to cyberinfrastructure to education. The scientific community benefits much from working with colleagues around the world that have other experiences, social cultures and knowledge bases. The US-LTER Network has and will continue to contribute to a significant effort at networking LTER programs in many countries (i.e., ILTER; International Long Term Ecological Network). Starting in 1993 at an All-Scientists meeting in the U.S. attended by scientists from seventeen countries, the program has increased with thirty-eight countries working together in the ILTER Network (http://www.ilternet.edu/). This international effort consists of networks of scientists engaged in long-term, site-based ecological and socioeconomic research. The mission is to improve understanding of global 
ecosystems and inform solutions to current and future environmental problems. ILTER's ten-year goals are to:

1. Foster and promote collaboration and coordination among ecological researchers and research networks at local, regional and global scales

2. Improve comparability of long-term ecological data from sites around the world, and facilitate exchange and preservation of this data

3. Deliver scientific information to scientists, policymakers, and the public and develop best ecosystem management practices to meet the needs of decision-makers at multiple levels

4. Facilitate education of the next generation of long-term scientists

Ultimately, the ILTER mission incorporates understanding of the role of humans in the environment to inform policy makers and translate understanding into action. Ecological issues cross national boundaries, and with the appropriate infrastructure for collaboration and globally distributed sets of resources, data and expertise, groups collaborating in the ILTER initiative can work at the scale of the ecological question. Also, just as students who are trained to work in interdisciplinary teams are better able to address the science of the future, students who can work in multi-cultural teams will be better able to compete in the global workforce and will be better in problem solving.

\section{Challenges for LTER type research}

The long-term sustainability of any research enterprise requires close coordination of goals among research teams and funding entities. Even with close coordination and excellent communication, many challenges face those who would organize a research program spanning decades. These challenges include the most fundamental question: How can a stable flow of funding be ensured to protect the long-term research investment? However, other key challenges include the building and maintenance of trust between funding agencies and researchers, the potential long-term effects of inflation, the development of appropriate funding partnerships that do not dilute the primary research goals, the development of mechanisms to assure smooth transitions in the research team across generations, and the many potential problems in coordinating a science program distributed among discrete sites and research teams. All of these challenges also present important opportunities to strengthen long-term research activities, but each problem must be identified and specifically addressed to ensure success. The experience of the US-LTER Network provides

insights into mechanisms to address issues relating to inflation, partnerships, transitions, and communication.

Inflation and the unique nature of long-term research programs - Long-term research programs produce useful results even in the early stages of 
experiments and observations, but the ultimate values of increased understanding of lag effects, long-term change, and development of new concepts and principles from the research may be years or decades removed from the initiation of the program. This unique characteristic of long-term research has important implications for planning a long-term research program. Specifically, inflation in the cost of labor and analyses can be significant when compounded over the life of a long-term study. In a constant funding environment with inflationary increases at best, long-term experiments can constitute a growing fraction of the total research budget, and this eventuality should be recognized and planned for from the beginning of the program. Some observations may need to be phased out over time to protect investments in long-term experiments. Alternatively, additional sources of funding may have to be sought to insure continuity of selected components of the program. The question of inflation is also important for funding agencies, who may find that their long-term programs create budgetary pressure on other research programs over time.

Partnerships as a method to sustain growth - A diversified funding portfolio provides protection from short-term changes in research support. One way to achieve diversification of funding is to establish partnerships among institutions and agencles that share common goals. Many of the US-LTER sites have entered into mutually-beneficial partnerships with the owners or stewards of their research sites, whether these are government agencies, non-government organizations, or private individuals. These partnerships can produce direct funding for research, but more often they result in in-kind support that reduces the funding that must be raised from competitive sources and can buffer the research program against fluctuations in external funding. Such partnerships are also important in identifying new research directions and applications that in themselves may generate increased support. The U.S. Department of Agriculture (USDA) has been an important partner of the US-LTER program in forest, rangeland, and agricultural sites, to the extent that the USDA has developed parallel efforts such as the Long Term Agricultural Research (LTAR; Robertson et al. 2008) and the Urban Long Term Research Area (ULTRA; http://www.nrs.fs.fed.us/urban/ultra/) programs.

Sustaining long-term research across generations - One unique challenge of long-term research is to maintain continuity in objectives in the face of changes in personnel and leadership that inevitably occur over the course of time. The USLTER program has been in existence long enough (28 years at this writing) to experience considerable turnover in personnel, and there are numerous sites where LTER graduate students have, over time, moved into leadership positions in the research team (Magnuson 2006). From the experience of the US-LTER, changes in leadership are particularly important events that must be planned for carefully. Many of the problems that have arisen with research programs at USLTER sites have been related to changes in leadership, especially where individuals have exerted strong influence on research goals. Many sites address 
this problem by having inclusive leadership teams and well-defined plans for leadership succession.

Linking sites, scientists, and data sources - Networked long-term research programs require attention to communication and cooperation at two levels, within and among research teams. Individual scientists engaged in US-LTER research form relationships with colleagues that may last most of their research careers. The research teams so formed are dynamic and need to adapt to changes in their composition and to shifts in individual objectives over time. Team leaders need to foster communication and cooperation, especially when team members are from different institutions. The problem of communication is even more acute among sites, where the total number of researchers is greater and the geographic distribution greater. The US-LTER has addressed these challenges by focused efforts to bring site leaders together frequently and to involve the whole US-LTER community in a joint meeting every three years. One of the most important reasons to foster communication among sites is to encourage data sharing for comparison and synthesis. Data managers from each of the 26 sites have developed a well-integrated working group that provides for coordination of data access through a network information system. Other disciplinary groups (e.g., climate, social science) provide additional opportunitjes to foster communication among sites.

\section{New challenges for the US-LTER Program}

As the US-LTER Network approached its fourth successful decade of scientific achievement in the ecological sciences, it undertook a significant self-analysis and planning strategy for future research and education. Starting in the late 1990 's, the Network challenged itself to develop additional advancements in Network science and a new kind of transdisciplinary science - one that ranges from local to global in scope, and that blends ecological and social science theories, methods, and interpretations in order to better understand and forecast environmental change in an era when no ecosystem on Earth is free from human influence. Seven years of planning resulted in a science plan, Integrative Science for Society and the Environment (LTER 2007; see also http://www.Iternet.edu/decadalplan/), which was submitted to the National Science Foundation. This effort describes a unifying framework that proposes to understand how humans perceive the critical services provided by ecosystems at multiple human scales, how these perceptions change behavior and institutions, and how these changes in turn feed back to affect ecosystem structure and function and the ability of ecosystems to continue to deliver services over the long term. The details of the Plan involve a set of research themes pursued over the next decade and beyond. Land and water use change; climate change, variability, and extreme events; and nutrient mobilization and species introductions all are considered grand challenges in environmental science and all are important to society. They also affect every site in the Network - indeed, every part of the U.S. - and are intractable without full consideration of social- 
ecological interactions. These particular themes are also among those that best match the research strengths of the Network. They can be best addressed with new long-term datasets, cross-site experiments, and modeling activities.

At each of the Network's 26 sites there is an extraordinary amount of knowledge about the organisms and processes important at the site, about the way the site's ecosystems respond to disturbance, and about long-term environmental change. A growing number of cross-site observations and experiments also have revealed much about the way that key processes, organisms, and ecological attributes are organized and behave across major environmental gradients. The contributions of basic knowledge of ecological interactions, ability to forecast change, and testing ecological theory are well recognized by the scientific community.

The Science Plan involves a comprehensive summary of existing long-term datasets along with detailed blueprints for the education and cyberinfrastructure resources that will be crucial for its success. The cyberinfrastructure plans include building capacities to increase data acquisition, management, and curation at the site level; to increase data discovery, access, and integration at the Network level; to increase modeling and analysis activities; and to integrate cyberinfrastructure into social ecological research, education, and training.

Linking research and education - Education plays a key role in US-LTER because of the need to inform and train the next generation of environmental scientists, inform the general public about ecosystem services to develop socialecological change, and educate the public about the need for research. The Strategic Plan for Education in the US-LTER Network promotes a vision of an environmentally literate citizenry able to make informed choices about complex environmental issues and includes five parts: 1) a scientific endeavor that continues, builds on, and celebrates its rich history of basic scientific discovery; 2) a society with the environmental science literacy needed for sound environmental citizenship and thereby a society that makes best use of timely, accurate, and unbiased information in decision making, including the capacity to act proactively and with forethought; 3 ) engagement of the full spectrum of our diverse society in developing and applying understanding of environmental challenges; 4) a scientific community that is receptive and responsive to the knowledge needs of the public and is committed to the delivery of knowledge in a useful form; 5) an environmental research and education enterprise informed by an understanding of the science/society interface. Achieving this vision will require strategic initiatives to (1) develop leadership, organization, and cyberinfrastructure, (2) promote research and development around our goals of environmental science literacy and inclusion of diverse people and perspectives, and (3) develop programs for specific constituent groups: $\mathrm{K}-12$ teachers and administrators, undergraduate and graduate students and professors, and active citizens. 
Social ecology - Processes and technologies for using and maintaining ecosystem services depend on fundamental advances in scientific understanding of social-ecological systems. These systems are the basis of human well-being. Societies face a challenge of improving human well-being while maintaining current and future ecosystem services. The US-LTER Network is poised to contribute to that understanding through the social and ecological research described in its plan: 1) LTER sites will seek to understand social-ecological dynamics connecting human cognition, attitudes, behaviors, and institutions with ecological structures and processes. This will include understanding variations and similarities influencing human decision making among disparate social groups and under different social and ecological conditions (both in place and time; 2) LTER sites will regionalize in order to understand these social-ecological dynamics in more diverse social-ecological contexts than they traditionally have pursued; 3) LTER sites will combine a long-term, spatially extensive, and multiscale approach to understand these social-ecological dynamics in a regional context. This will expose temporal lags, spatial dependencies, and scale mismatches that generate decision-making surprises and sudden shifts; and 4) education will be both an activity and an object of study, engaging students and the public in the generation of ecological knowledge, sharing that knowledge broadly, and learning how to transmit ecological knowledge more effectively. The existing LTER connections between research and decision-making applications - public, non-profit, and private sectors - are likely to increase over time because of the enduring collaborations that are fostered by the longterm nature of US-LTER sites.

\section{Summary}

Long-term ecological research grew out of a history of ecosystem studies and from growing experience with large-scale interdisciplinary programs. The U.S. Long Term Ecological Research (US-LTER) program consists of 26 research sites involving a wide range of ecosystem types and concentrates on the interactions of multiple ecosystem processes that play out at time scales spanning decades to centuries. This focuses US-LTER research between the most common time scales for ecological studies (1-3 years) and the much longer temporal foci of disciplines such as paleoecology. Long-term data sets from programs such as US-LTER provide a context to evaluate the pace of ecological change, to interpret its effects, and to forecast the range of future biological responses to change.

Many issues and challenges are associated with maintaining a successful longterm research network. Governing an expanding network at both the US and international levels requires management techniques that emphasize the coordination and management of the complexity inherent in network-level science. The US program involves a 60-member Science Council to address science-related efforts and bylaw revisions and a 12-member elected Executive Board authorized to act on the Council's behalf. Incorporating international 
awareness and participation is a critical aspect of the US-LTER Network initiative-from research to cyberinfrastructure to education. The scientific community benefits much from working with colleagues around the world that have other experiences, social cultures and knowledge bases. The LTER Network contributes to a significant effort at networking LTER programs in many countries (i.e., ILTER; International Long Term Ecological Network). Ultimately, the ILTER mission incorporates understanding of the role of humans in the environment to inform policy makers and translate understanding into action.

The primary challenges for LTER type research during its history involved sustaining funding, partnership development to sustain growth, maintaining continulty in objectives, and linking scientists and data through communication and cooperation. These challenges have been successfully addressed over the decades of the US-LTER program through close cooperation and coordination of the scientific community and the funding agencies for these programs.

Integrative Science for Society and the Environment provides a framework to understand the interactions between critical ecosystern services, human perception of these services, and the behavior of individuals and institutions based on these perceptions. Education plays a key role in this plan, with the goal of an environmentally literate citizenry able to make informed choices about complex environmental issues.

\section{Literature Cited}

Abramson, G. and V. M. Kenkre (2002). Spatio-temporal patterns in the hantavirus infection. Physiological Review E 66, 011912-1-5.

Benstead J.P., March J.G., Pringle C.M., Scatena F.N. 1999. Effects of a lowhead dam and water abstraction on migratory tropical stream biota. Ecological Applications 9: 656-668.

Callahan, J. T. 1984. Long-term ecological research. BloScience 34:363-367.

Childs, J. E, et al. (1994). Serologic and genetic identification of Peromyscus maniculatus as the primary rodent reservoir for a new hantavirus in the southwestern United States. J. Infect. Dis. 169, 1271-1280.

Corujo, I. N. 1980. A study of fish populations in the Espiritu Santo River Estuary. Master's thesis. University of Puerto Rico, Rio Pledras.

Edmondson, W. T. 1991. The uses of ecology: Lake Washington and beyond. University of Washington Press, Seattle, Washington, USA

Fievet E, L. Tito de Morais, A. Tito de Morais, D. Monti, and H. Tachet. 2001 a. Impacts of an irrigation and hydroelectric scheme in a stream with a high rate of 
diadromy (Guadeloupe, Lesser Antilles): Can downstream alterations affect upstream faunal assemblages? Archiv für Hydrobiologie 151: 405-425.

Forbes, S. A. 1887. The lake as a microcosm. Bulletin of the Peoria Science Association, Illinois Natural History Survey Bulletin 15:537-550.

Franklin, J. F., C. S. Bledsoe, and J. T. Callahan. 1990. Contributions of the Long-term Ecological Research Program. BioScience 40:509-523.

Golley, F. B. 1993. A history of the ecosystem concept in ecology: more than the sum of the parts. Yale University Press, New Haven, Conneticut, USA.

Hobbie, J. E. ; Carpenter, S. R. ; Grimm, N. B. ; Gosz, J. R. ; Seastedt, T. R.. 2003. The US Long Term Ecological Research program. Bioscience. Bioscience $53: 21-32$

Institute of Ecology. 1977. Experimental ecological reserves: a proposed national network. p.40. Washington D.C.: National Science Foundation.

Kratz, T. K., B. J. Benson, E. R. Blood, G. L. Cunningham, and R. A. Dahlgren. 1991. The influence of landscape position on temporal variability in four North American ecosystems. American Naturalist 138:355-378.

Kratz, T. K., J. J. Magnuson, P. Bayley, B. J. Benson, C. W. Berish, C. S. Bledsoe, E. R. Blood, C. J. Bowser, S. R. Carpenter, G. L. Cunningham, R. A. Dahlgren, T. M. Frost, J. C. Halfpenny, J. D. Hansen, D. Heisey, R. S. Inouye, D. W. Kaufman, A. McKee, and J. Yarie. 1995. Temporal and spatial variability as neglected ecosystem properties: lessons learned from 12 North American ecosystems. Pages 359-383. in D. Rapport and P. Calow, editors. Evaluating and monitoring the health of large-scale ecosystems. Springer-Verlag, New York, New York, USA.

Kratz, T. K., K. E. Webster, C. J. Bowser, J. J. Magnuson, and B. J. Benson. 1997. The influence of landscape position on lakes in northern Wisconsin. Freshwater Biology 37:209-217.

Kratz, T. K., K. E. Webster, J. L. Riera, D. B. Lewis, and A. I. Pollard. 2006. Making Sense of the landscape: Geomorphic legacies and the landscape position of lakes. Pages 49-66 in Magnuson, J. J., T. K. Kratz, and B. J. Benson, eds. Long-Term Dynamics of Lakes in the Landscape: Long-Term Ecological Research on North Temperate Lakes. Oxford University Press.

Likens, G. E., F. H. Borman, R. S. Pierce, J. S. Eaton, and N. M. Johnson. 1977. Biogeochemistry of a forested ecosystem. Springer-Verlag, New York, New York, USA. 
Lindeman, R. L. 1942. The trophic-dynamic aspect of ecology. Ecology 23:399418.

LTER 2007. The Decadal Plan for LTER: Integrative Science for Society and the Environment. LTER Network Office Publication Series No. 24, Albuquerque, New Mexico. 154 pages.

Magnuson, J. J. 1990. Long-term ecological research and the invisible present. BioScience 40:495-501.

Magnuson, J. J., T. K. Kratz, T. M. Frost, C. J. Bowser, B. J. Benson, and R. Nero. 1991. Expanding the temporal and spatial scales of ecological research and comparison of divergent ecosystems: roles for the LTER in the United States. in P. G. Risser, editor. Long-term ecological research. John Wiley \& Sons, Sussex, England.

Magnuson, J. J., and T. K. Kratz. 2000. Lakes in the landscape: approaches to regional limnology. Verhandlungen Internationale Vereinigung fur Limnologie $27: 74-87$.

Magnuson, J. J., T. K. Kratz, and B. J. Benson 2006. Long-Term Dynamics of Lakes in the Landscape: Long-Term Ecological Research on North Temperate Lakes. xix $+400 p$. Oxford University Press, New York.

March J.G., J.P. Benstead, C.M. Pringle, and M.R. Ruebel. 2001. Linking shrimp assemblages with rates of detrital processing along an elevational gradient in a tropical stream. Canadian Journal of Fisheries and Aquatic Sciences 58: 470478.

March J.G., Pringle C.M.,Townsend M.J., and Wilson A.I..2002. Effects of freshwater shrimp assemblages on benthic communities along an altitudinal gradient of a tropical island stream. Freshwater Biology 47: 377-390.

March, J.G., J.P. Benstead, C. M. Pringle, and F. N. Scatena. 2003. Damming tropical island streams: Problems, solutions, and alternatives. BioScience 53:1069-1078.

Marzolf, G. R. 1982. Long-term ecological research in the United States: a network of research sites, 1982. Pages i. in J. C. I. Halfpenny, K., and Hardesty, J., editor. Long-Term Ecological Research (LTER) Network.

Michener, W.K. and J.W. Brunt. 2000. Ecological Data: Design, Management and Processing. Blackwell Science, Oxford, UK. $180 \mathrm{pp}$.

Millennium Ecosystem Assessment. 2005. Ecosystems and human well-being: current state and trends. Island Press, Washington, DC. 
Mills, J. N., T. G. Ksiazek, C. J. Peters and J. E. Childs (1999). Long-term studies of hantavirus reservoir populations in the southwestern United States: a synthesis. Emerging Infect. Dis. 5, 135-142.

Nichol, S. T., C. F. Spiropoulou, S. Morzunov, P. E. Rollin, T. G. Ksiazek, H. Feldmann, A. Sanchez, J. Childs, S. Zaki and C. J. Peters (1993). Genetic identification of a hantavirus associated with an outbreak of acute respiratory illness. Science 262, 914-917.

Ortiz-Zayas, J. R. and F. N. Scatena. 2004. Integrated water resources management in the Luquillo Mountains, Puerto Rico: An evolving process. Water Resources Development 20:387-398.

Parmenter, C. A., T. L. Yates, R. R. Parmenter, J. N. Mills, J. E. Childs, M. L. Campbell, J. L. Dunnum and J. Milner (1998). Small mammal survival and trapability in mark recapture monitoring programs for hantavirus. J. Wildl. Dis. 34, $1-12$.

Parmenter, R. R., J. W. Brunt, D. I. Moore and E. S. Morgan (1993). The Hantavirus Epidemic in the Southwest: Rodent Population Dynamics and the Implications For Transmission of Hantavirus-associated Adult Respiratory Distress Syndrome (HARDS) in the Four Corners Region. Sevilleta LTER Publication No. 41, pp. 1-45.

Pringle C.M., N. Hemphill, W. H. McDowell, A. Bednarek, and J. G. March. 1999. Linking species and ecosystems: Effects of different macrobiotic assemblages on interstream differences in benthic organic matter. Ecology 80: 1860-1872.

Pringle CM. 1997. Exploring how disturbance is transmitted upstream: Going against the flow. Journal of the North American Benthological Society 16: 425438.

Riera, J. L., J. J. Magnuson, T. K. Kratz, and K. E. Webster. 2000. A geomorphic template for the analysis of lake districts applied to the Northern Highland Lake District, Wisconsin, USA. Freshwater Biology 43:301-318.

Robertson, G. P., V. G. Allen, G. Boody, E. R. Boose, N. G. Creamer, L. E. Drinkwater, J. R. Gosz, L. Lynch, J. L. Havlin, L. E. Jackson, S. T. A. Pickett, L. Pitelka, A. Randall, A. S. Reed, T. R. Seastedt, R. B. Waide, and D. H. Wall. 2008. Long-Term Agricultural Research (LTAR): A Research, Education, and Extension Imperative. BioScience 58: 640-645.

Rosenberg DM, McCully P, Pringle CM. 2000. Global-scale environmental effects of hydrological alterations. BioScience 50: 746-751. Water Resources

Development, Vol. 20, No. 3, 387-398, September 2004 
Swanson, F. J., and R. E. Sparks. 1990. Long-term ecological research and the invisible place. BioScience 40:502-508.

Tansley, A. G. 1935. The use and abuse of vegetational concepts and terms. Ecology 16:284-307.

Thorp, J. H., and M. D. Delong. 1994. The Riverine Productivity model - an Heuristic view of carbon-sources and organic-processing in large river ecosystems. Oikos 70:305-308.

Tilman, D. 1989. Ecological experimentation: strengths and conceptual problems. Pages 136-157 in G. E. Likens, Ed., Long-Term Studies in Ecology: Approaches and Alternatives. Springer-Verlag, 1989.

Vannote, R. L., G. W. Minshall, K. W. Cummins, J. R. Sedell, and C. E. Cushing. 1980. The river continuum concept. Canadian Journal of Fisheries and Aquatic Sciences 37:130-137.

Webster, K. E., T. K. Kratz, C. J. Bowser, J. J. Magnuson, and W. J. Rose. 1996. The influence of landscape position on lake chemical responses to drought in northern Wisconsin. Limnology and Oceanography 41:977m-984.

Webster, K. E., P. A. Soranno, S. B. Baines, T. K. Kratz, C. J. Bowser, P. J. Dillon, P. Campbell, E. J. Fee, and R. E. Hecky. 2000. Structuring features of lake districts: landscape controls on lake chemical responses to drought. Freshwater Blology 43:499-515.

Webster, K. E., C. J. Bowser, M. P. Anderson, and J. D. Lenters. 2006. Understanding the lake-groundwater system: Just follow the water. Pages 19-48 in Magnuson, J. J., T. K. Kratz, and B. J. Benson, eds. Long-Term Dynamics of Lakes in the Landscape: Long-Term Ecological Research on North Temperate Lakes. Oxford University Press.

Yates, T. L. et al. (2002). The ecology and evolutionary history of an emergent disease: hantavirus pulmonary syndrome. Bioscience 52, 989-998. 


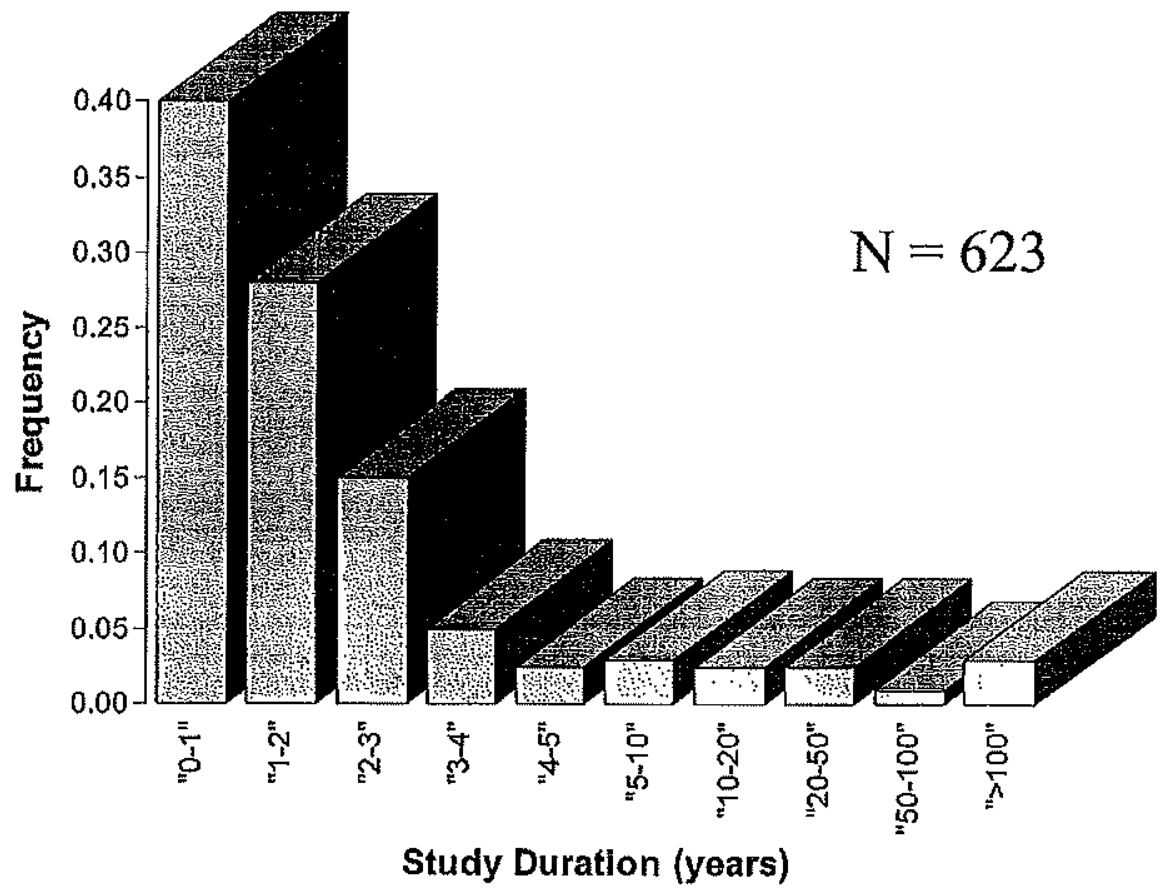

Figure 1. Duration of observational and experimental studies randomly-selected from Ecology between the years 1977-1987. From Tilman 1989. 


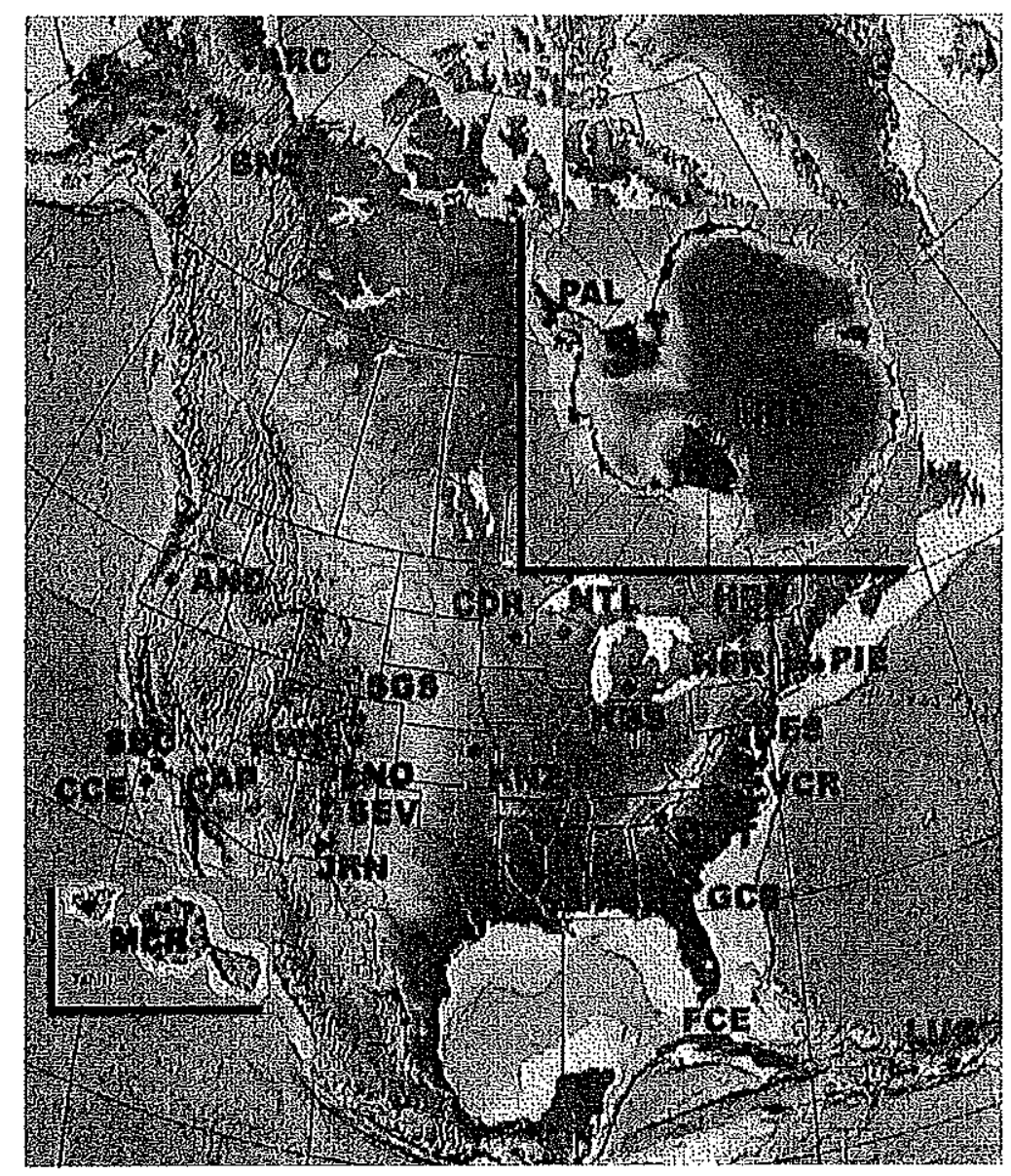

Figure 2. Location of sites in the US LTER Network.

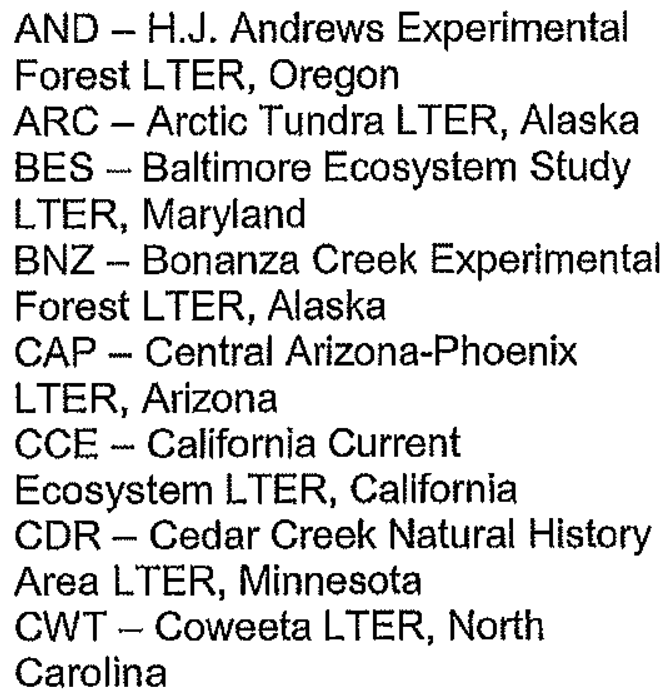

AND - H.J. Andrews Experimental Forest LTER, Oregon

ARC - Arctic Tundra LTER, Alaska

BES - Baltimore Ecosystem Study

LTER, Maryland

BNZ - Bonanza Creek Experimental

Forest LTER, Alaska

CAP - Central Arizona-Phoenix

LTER, Arizona

CCE - California Current

Ecosystem LTER, California

CDR - Cedar Creek Natural History

Area LTER, Minnesota

CWT - Coweeta LTER, North

Carolina

FCE - Florida Coastal Everglades

LTER, Florida

GCE - Georgia Coastal Ecosystem

LTER, Georgia

HBR - Hubbard Brook LTER, New

Hampshire

HFR - Harvard Forest LTER,

Massachusetts

JRN - Jornada Basin LTER, New

Mexico

KBS - Kellogg Biological Station

LTER, Michigan

KNZ - Konza Prairie LTER, Kansas

LUQ - Luquillo Experimental Forest

LTER, Puerto Rico 
MCM - McMurdo Dry Valleys LTER, Antarctica MCR - Moorea Coral Reef LTER, French Polynesia NWT - Niwot Ridge LTER, Colorado NTL - North Temperate Lakes LTER, Wisconsin

PAL - Palmer Station LTER, Antarctica
PIE - Plum Island Ecosystem LTER, Massachusetts

SBC -. Santa Barbara Coastal Ecosystem LTER, California

SEV - Sevilleta LTER, New Mexico SGS - Shortgrass Steppe LTER, Colorado

VCR - Virginia Coast Reserve LTER, Virginia 
Figure 3. Fall-spring precipitation is significantly correlated with spring Peromyscus densities a year later $(r=0.797, \mathrm{df}=9, p<.01)$ at the Sevilleta LTER site. High rodent density in 1993 and 1998-1999 reflect post El Nino periods and coincide with the initial Four Corners Hantavirus outbreak in 1993 and increased prevalence of seropositive individuals sampled from the Four Corners area in 1998-1999. Figure by Michael T. Friggens from data published in Yates et al 2002.

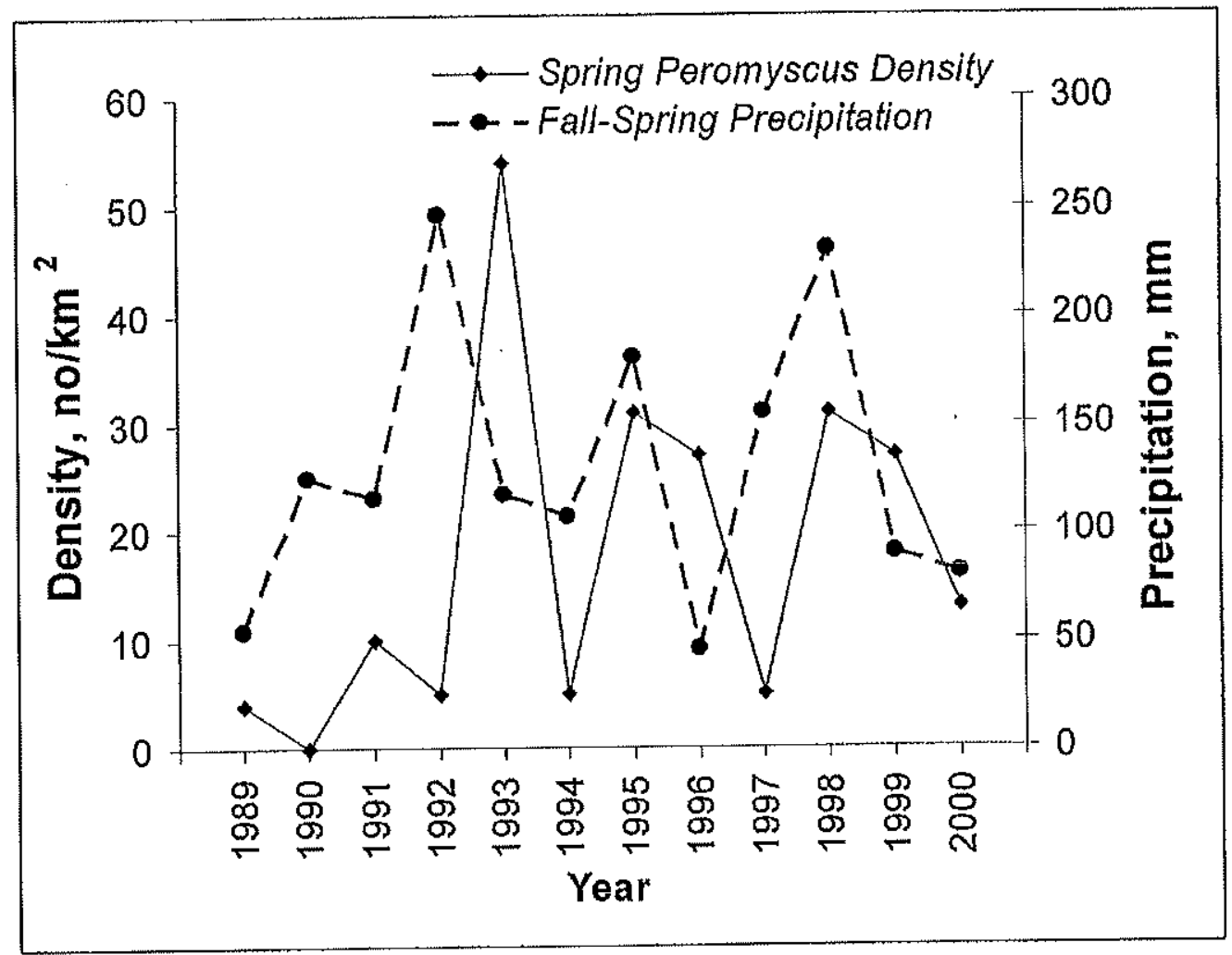


Figure 4. Lake surface area, conductivity, and fish species richness as a function of landscape position for the seven primary LTER lakes in northern Wisconsin (modified from Kratz and et al. 1997 and Kratz et al. 2006).

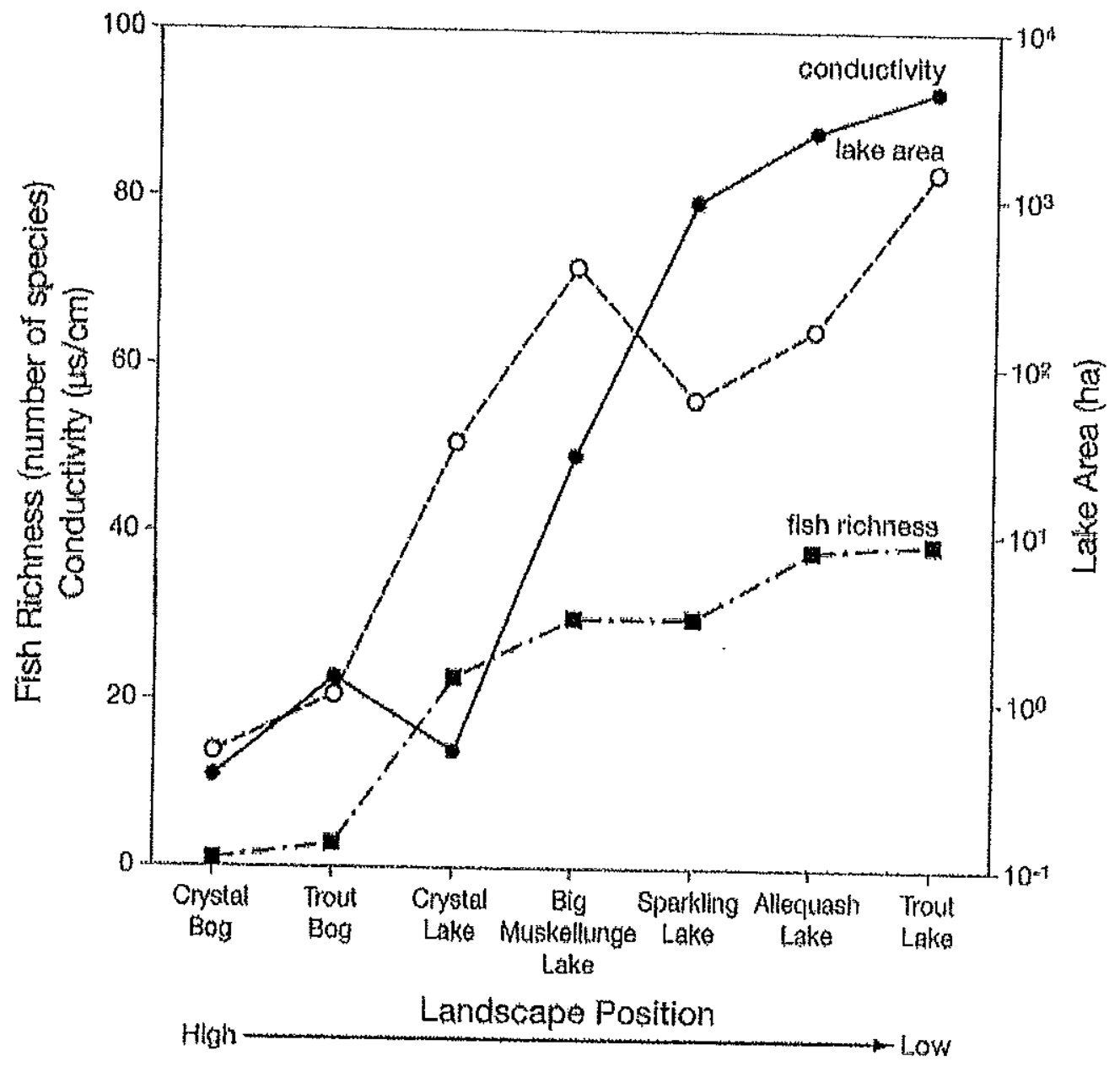




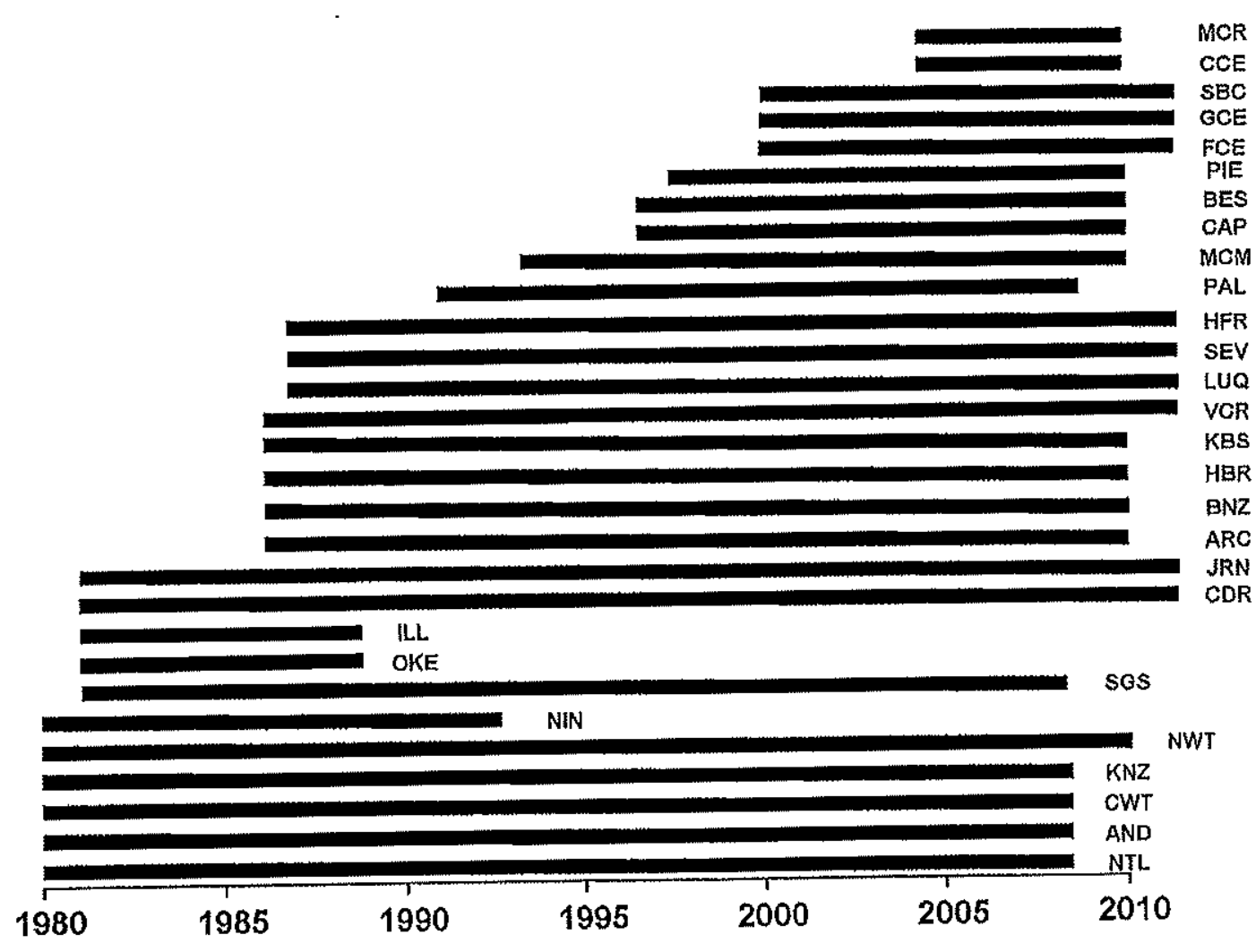

Figure 5. Incremental addition of sites to the US-LTER Network. Initial cohorts were funded primarily by the Division of Environmental Biology of the National Science Foundation, but other Directorates added funding for specific sites. 


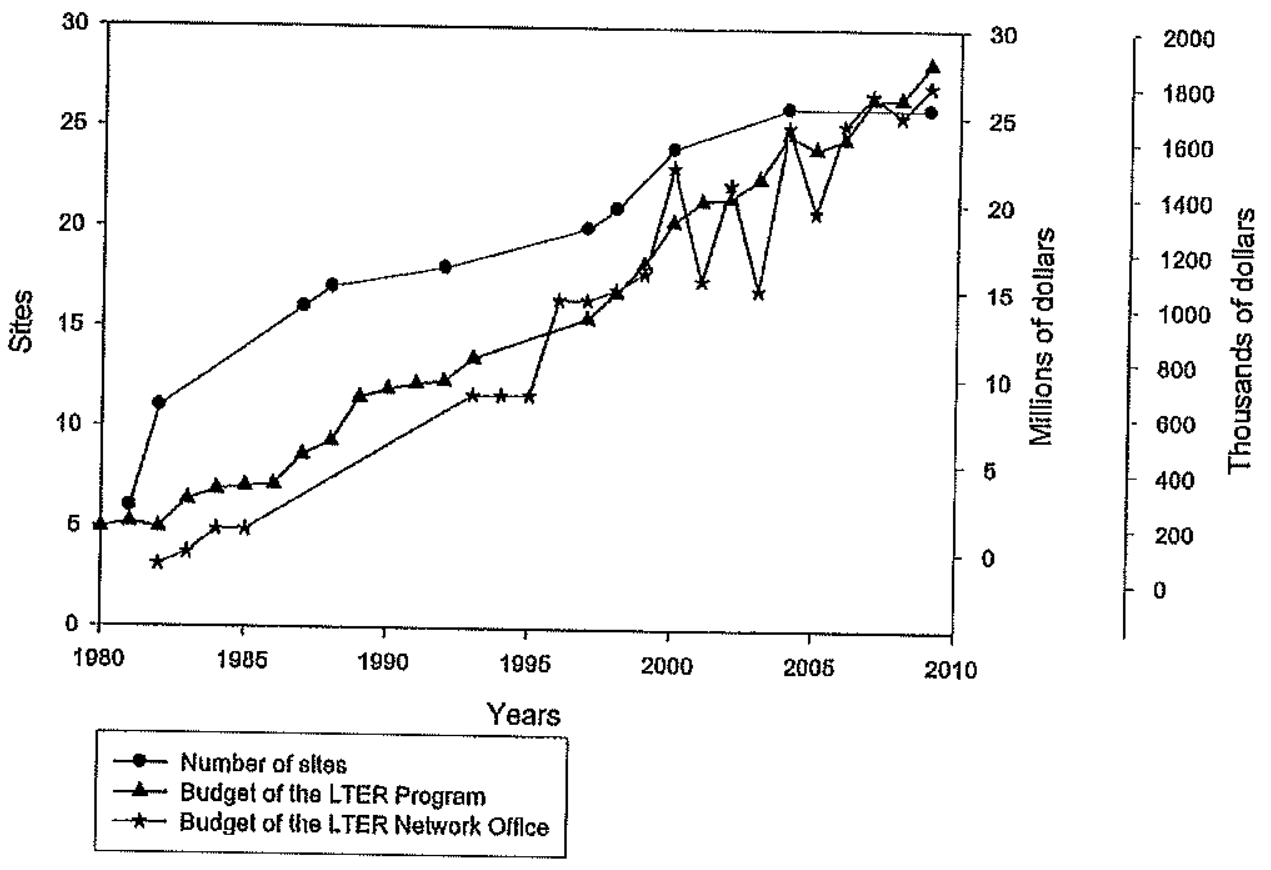

Figure 6. Growth of the LTER Network since its inception. The overall increase in funding reflects a combination of increasing numbers of sites and increasing funding for each site. The budget of the LTER Network Office, which coordinates and supports Network activities, has grown at a pace with the Network budget. 
Figure 7. Governance structure of the LTER Network in the shaded box. Twenty-six sites provide members to the Science Council, Executive Board, and standing committees.

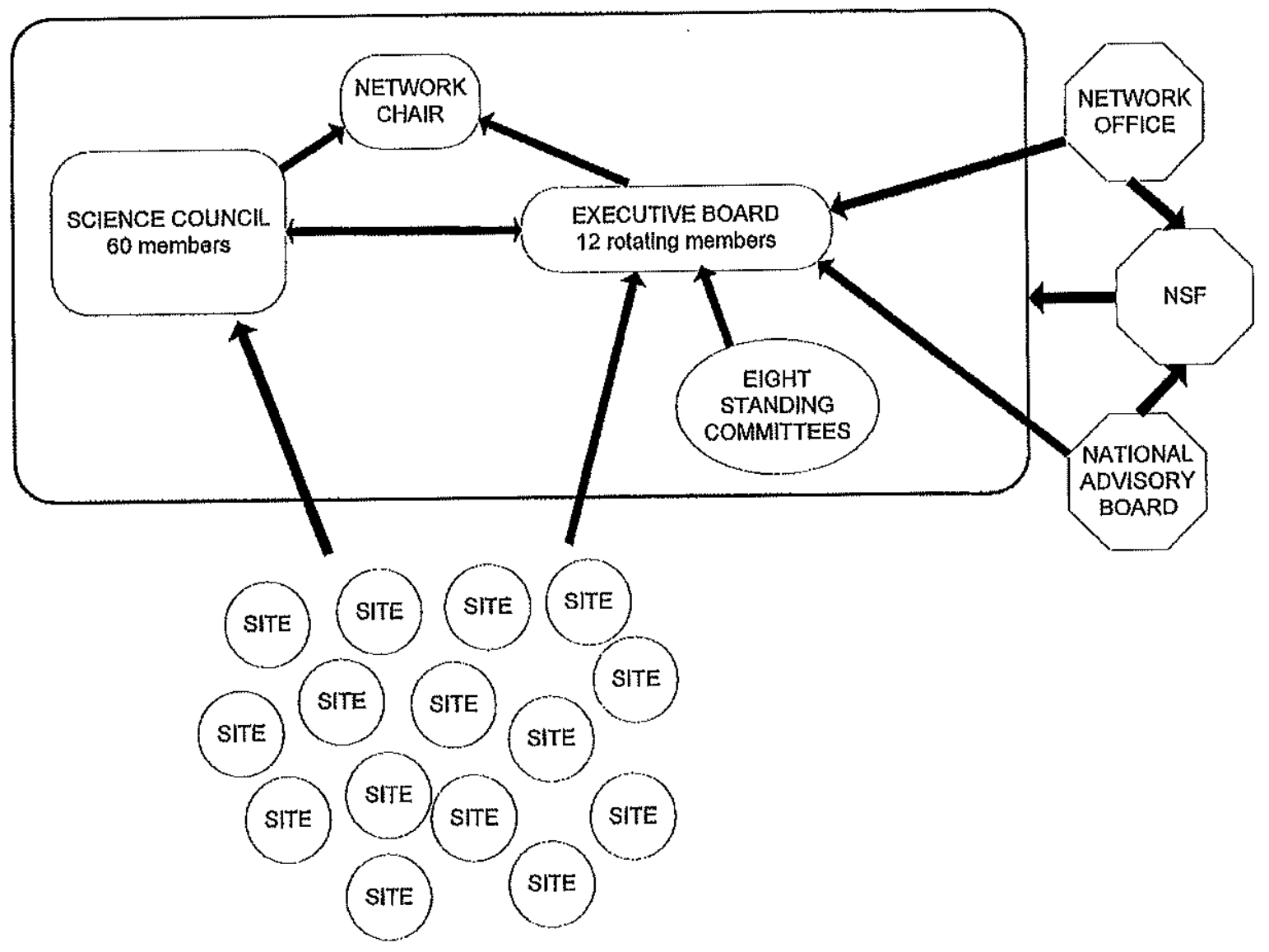

